\title{
A Suspensão Da Prescrição Trabalhista Em Tempos De Pandemia
}

\author{
Bruno Gomes Borges da Fonseca* \\ Universidade Federal do Espírito Santo, Programa de Mestrado Profissional em Gestão \\ Pública, Colatina-ES, Brasil. \\ (iD) https://orcid.org/0000-0001-9294-6650 \\ Vitor Salino de Moura Eça** \\ PUC Minas Gerais, Programa de Pós-graduação em Direito, Belo-Horizonte-MG, Brasil. \\ (iD https://orcid.org/0000-0002-8408-6213

\begin{abstract}
Stela Barbas***
Universidade Autónoma de Lisboa, Pós-Graduação de Registos e Prática Notarial, Lisboa, Portugal.

iD https://orcid.org/o0o0-0002-8488-3669
\end{abstract}

\begin{abstract}
Resumo: Este artigo analisa se uma pandemia, como a gerada pelo vírus Sars-CoV2 (coronavírus), possui o condão de impedir ou suspender a contagem do prazo prescricional da pretensão de direitos trabalhistas. A hipótese é no sentido de que os prazos prescricionais trabalhistas, nessa situação de anormalidade, não iniciam sua contagem ou são suspensos, embasado em uma interpretação pautada pelo direito de acesso à jurisdição. Em razão de inúmeras controvérsias jurídicas surgidas a partir da pandemia, inclusive acerca da contagem do prazo de prescrição, coloca-se como objetivo analisar a prescrição em seus aspectos gerais, bem como analisar o impedimento e a suspensão da contagem do prazo da prescrição trabalhista em períodos pandêmicos, a partir do exemplo da covid-19. Adota-se, para tanto, a abordagem dialética, pela possibilidade de extração de contradições e antagonismos em torno da prescrição de pretensões trabalhistas e por sinalizar alternativas em um momento pandêmico. Neste sentido, conclui-se que as hipóteses de impedimento e suspensão da contagem do prazo prescricional, previstas no Código Civil, são aplicáveis ao direito do trabalho. Entretanto devem ser analisadas a partir de uma leitura constitucional e com a observação de que a prescrição, nesse ramo jurídico especializado, possui restrições e particularidades. A par disso, pandemias, como a gerada pelo vírus Sars-CoV-2 (coronavírus), podem resultar no impedimento ou na suspensão da contagem do prazo prescricional de pretensões decorrentes de violações a direitos trabalhistas, caso haja comprovação de obstáculo ou justo impedimento de acesso à jurisdição, algo confirmado, em parte, pela Lei n. 14.010/2020.
\end{abstract}

Palavras-chave: Direito do trabalho. Processo do trabalho. Covid-19. Coronavírus. Prazo prescricional.

* Doutor em Direito pela Faculdade de Direito de Vitória (FDV). Professor da FDV e do Programa de Mestrado Profissional em Gestão Pública da UFES. E-mail: bgbfonseca@yahoo.com.br

** Doutor em Direito pela PUC- Minas. Professor do Programa de mestrado e doutorado em Direito da PUC-Minas. E-mail: profvitorsalino@gmail.com

*** Doutora em Direito pela Universidade Autónoma de Lisboa. Professora Associada da UAL. E-mail: bgbfonseca@yahoo.com.br

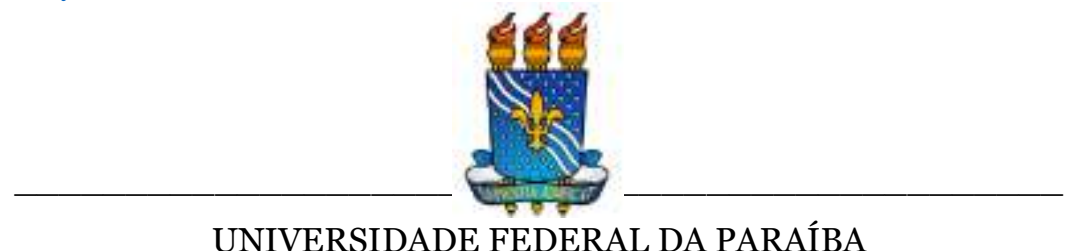

Programa de Pós-Graduação em Ciências Jurídicas

DOI: https://doi.org/10.22478/ufpb.1678-2593.2020v19n42.53334 


\title{
A Suspensão Da Prescrição Trabalhista Em Tempos De Pandemia
}

\author{
Bruno Gomes Borges da Fonseca
}

Vitor Salino de Moura Eça

Stela Stela Barbas

1 INTRODUÇÃO'

No início do ano 2020, a população mundial foi compelida a modificar seus hábitos e alterar, abruptamente, a rotina em decorrência da descoberta de uma nova doença (covid-19), causada pelo Sars-CoV-2 (coronavírus). Este vírus, conforme informação extraída do portal do Ministério da Saúde, pertence a uma família de vírus que causam infecções respiratórias, cujo novo agente foi descoberto, em 31 de dezembro de 2019, depois de casos registrados na China. (BRASIL, 2020a).

Nesse contexto, vários países tomaram providências no sentido de tentar impedir o avanço do vírus em seus territórios e conscientizar as pessoas da necessidade do recolhimento social, diante das possibilidades de contaminação em massa e da insuficiência dos respectivos sistemas de saúde. No Brasil, as mobilizações mais drásticas, para conter a doença, tiveram início na terceira semana de março de 2020.

Tais ações foram implementadas com o escopo de forçar a manutenção dos indivíduos em suas residências, inclusive com

1 Alguns trechos constantes da introdução, com adaptações, foram extraídos de estudo ainda inédito (OLIVEIRA; FONSECA, 2020). 
adoção do trabalho a distância, e, consequentemente, diminuir a crescente demanda de internações nos hospitais, até que se descubra um tratamento eficaz ou uma vacina.

Nesse curso, foi publicada a Lei n. 13.979/2020 (BRASIL, 2020b), ${ }^{2}$ cujo texto dispôs sobre as medidas para enfrentamento da emergência de saúde pública de importância internacional decorrente do Sars-CoV-2 (coronavírus). Os arts. $6^{\circ}-\mathrm{C}$ e $6^{\circ}-\mathrm{D}$, deste ato normativo, suspenderam alguns prazos processuais, todavia, se abstiveram de dispor sobre o prazo prescricional.

Concomitantemente, foram editadas medidas provisórias pelo Presidente da República, cujos termos dispõem, entre outros assuntos, sobre as relações empregatícias e de trabalho, além da concessão de renda emergencial para os grupos mais vulneráveis da sociedade e apoio financeiro aos empregadores, em tempos de pandemia. Um desses atos normativos foi a então vigente (não ratificada pelo Congresso Nacional) Medida Provisória n. 927/2020 (BRASIL, 2020c), cujo texto dispunha sobre as medidas trabalhistas para enfrentamento do estado de calamidade pública e da emergência de saúde pública decorrentes da covid-19. Em uma de suas previsões (art. $1^{\circ}$, parágrafo único), para os fins do direito do trabalho, reconheceu estado de força maior, entretanto, nada dispôs sobre os prazos prescricionais.

O Conselho Nacional de Justiça (CNJ) igualmente editou Resoluções para tratar do funcionamento do Poder Judiciário no período pandêmico. Em linhas gerais, com algumas nuances a depender do tipo de autos (físico ou eletrônico), suspendeu a tramitação dos prazos processuais, sem, porém, carrear uma previsão específica sobre o impedimento ou suspensão da contagem dos prazos prescricionais.

\footnotetext{
${ }^{2}$ A partir deste ponto, as citações desta Lei não serão referenciadas. Adotar-se-á esta regra para todos os atos normativos (apenas para eles), com referência apenas na primeira citação, sem prejuízo de sua listagem ao final. O objetivo é conferir maior fluidez ao texto.
} 
Posteriormente, a Lei n. 14.010/2020 (BRASIL, 2020d), cujo texto dispõe sobre o regime jurídico emergencial e transitório das relações jurídicas de direito privado no período da pandemia, previu um capítulo sobre prescrição e decadência e consignou que os prazos prescricionais estão impedidos ou suspensos pelo período compreendido da sua vigência até 30 de outubro de 2020.

A partir desse contexto, esta pesquisa, sob a perspectiva do direito do trabalho, malgrado o intenso e necessário diálogo com o direito civil, possui como problema a análise do impedimento e/ou da suspensão do prazo prescricional das pretensões decorrentes de violações de direito do trabalho em períodos de pandemia. Para ser mais explícito, este estudo pretende analisar o seguinte problema: os prazos de prescrição trabalhista estão impedidos de serem iniciados ou suspensos em virtude de pandemia? A covid-19 é utilizada como exemplo, todavia, as conclusões poderão ser testadas a partir de qualquer momento pandêmico ou situações extremas similares.

A hipótese é no sentido de que os prazos prescricionais trabalhistas, em virtude de situações excepcionais como a pandemia gerada pelo Sars-CoV-2 (coronavírus), não iniciam sua contagem ou são suspensos, a partir de interpretação constitucional e sistemática pautada pelo direito de acesso à jurisdição.

Este estudo se justifica em razão das controvérsias surgidas em torno do impedimento ou da suspensão, ou não, do prazo de prescrição no direito do trabalho, no período da pandemia de covid19, o que vem gerando bastante insegurança jurídica. É motivado também pela ausência de escassez de estudos a respeito, o que obriga diálogo com correntes mais antigas sobre a possibilidade de se interpretar extensivamente as causas de impedimento e suspensão do prazo da prescrição, e uma interpretação constitucional da dogmática jurídica.

Com supedâneo neste problema, o trabalho se desenvolve com o objetivo de analisar o impedimento e a suspensão do prazo de 
prescrição da pretensão decorrente de violação a direito trabalhista em períodos pandêmicos, a partir do exemplo da covid-19.

Para tanto, utiliza-se como método de uma abordagem dialética, a qual parece capaz de sinalizar contradições e antagonismos na estipulação de um prazo prescricional para pretensões trabalhistas, algo, talvez, mais evidenciado quando se sustenta o início ou a continuidade do seu transcurso em um período de pandemia, o que, em última análise, pode propiciar a fulminação de direitos fundamentais dos trabalhadores e comprometer a efetividade do direito do trabalho. Essa abordagem metodológica, pautada em uma análise sistemática da ordem jurídica, parece adequado para identificar esses antagonismos e contradições e, sem negá-los, estruturar uma alternativa hermenêutica capaz de equacioná-los em um momento de tamanha excepcionalidade. Esta pesquisa adota a técnica de pesquisa documental indireta nas modalidades pesquisas documental e bibliográfica, ou seja, para a confecção deste estudo analisa documentos públicos, estatísticas, fontes normativas e bibliografia tornada pública. 3

\section{ASPECTOS GERAIS DA PRESCRIÇÃO}

Gomes (1987, p. 420) ressalta que, entre os acontecimentos naturais ordinários, o decurso do tempo é o que maior consequência gera nas relações jurídicas. A existência da prescrição corrobora o acerto da asserção. No direito é, certamente, um dos temas que mais impulsionou discussões teóricas. (MONTEIRO, 2016).

A prescrição é um instituto da teoria geral do direito. Nesta condição, parece tecnicamente equivocado (embora, didaticamente, aceitável) aludir-se à prescrição trabalhista, penal, civil, tributária 
etc. O que há, na verdade, são regras e princípios particulares aplicáveis à prescrição em cada ramo jurídico. Mesmo com esta ressalva, parece induvidoso que o direito civil apresenta os principais corpos dogmáticos e teóricos acerca do tema. Consequentemente, a abordagem desta seção, malgrado o necessário diálogo com o direito do trabalho, inicia-se a partir de uma perspectiva mais civilista.

O Código Civil (CC), promulgado em 2002 (BRASIL, 2020e), possui um título (Título IV) intitulado Da Prescrição $e$ da Decadência e um capítulo (Capítulo I) alusivo à prescrição, com dezessete artigos sobre o tema (arts. 189 a 206). A Consolidação das Leis do Trabalho - CLT (BRASIL, 2020f), por sua vez, possui menos dispositivos sobre o instituto, apesar de a previsão da prescrição, no direito do trabalho, estar sediada no art. $7^{\circ}$, XXIX, da Constituição Federal de 1988 (CF/1988) (BRASIL, 2019), o que contribui para tomada de outros caminhos hermenêuticos.

O CC, promulgado em 2002, quando cotejado com o CC de 1916 (BRASIL, 1972), evoluiu bastante ao adequar o capítulo alusivo à prescrição a teorias mais adequadas. No lugar de prescrição da ação, por exemplo, reconheceu sua incidência sobre a pretensão (arts. 189 e 190), isto é, a prescrição importa na extinção da exigibilidade de um direito em virtude do transcurso de certo tempo. (AZEVEDO, 2019; PAMPLONA FILHO; GAGLIANO, 2016). “[...] A pretensão não é direito nem ação; está entre eles [...]”. (LÔBO, 2020).

A prescrição, portanto, não atinge o direito de ação nem o direito subjetivo. Este, entretanto, perde seu poder de exigibilidade (pretensão) e está impedido, inclusive, de ser arguido na condição de tese defensiva (CC, art. 190). Para ser mais técnico, a prescrição não fulmina a pretensão. $\mathrm{Na}$ verdade, encobre a sua eficácia. (PAMPLONA FILHO; FERNANDES, p. 2018; LEONARDO, 2010).

O texto da CLT, como ocorreu com o CC promulgado em 2002, foi atualizado pela Reforma Trabalhista, consubstanciada pela Lei $\mathrm{n}$. 13.467/2017 (BRASIL, 2017), cujo resultado foi a promoção de 
similar alteração (art. 11), com o reconhecimento de que a prescrição fulmina a pretensão.

A prescrição é instituto antigo (praescriptio) presente no direito romano (WALD; CAVALCANTI; PAESANI, 2015). Geralmente, é classificada em aquisitiva (usucapião) e extintiva (esta é de interesse desta pesquisa). Segundo a doutrina ${ }^{4}$ civilista, o instituto encontra seus fundamentos em ideias volvidas à segurança jurídica, à estabilidade quanto às expectativas de conduta e à pacificação social. (BARROS, 2016; PAMPLONA FILHO; GAGLIANO, 2016; LÔBO, 2020). No direito do trabalho esta posição é igualmente prestigiada (SÜSSEKIND; MARANHÃO; VIANNA; TEIXEIRA, 1999, p. 1449), contudo também recebe tenaz crítica por se apresentar como um mecanismo de proteção à propriedade (em detrimento de direitos sociais) e de contenção de demandas. (SEVERO, 2017, p. 100).

Para concretização da prescrição, a partir da clássica lição de Leal (1982, p. 20), são necessários quatro elementos: a) existência de uma ação (leia-se pretensão exercitável); b) inércia do titular por se omitir em exercitá-la; c) continuidade dessa inércia durante um certo lapso de tempo; d) ausência de causas preclusivas em seu curso.

O prazo de prescrição nasce a partir da violação de um direito (critério do actio nata). Antes da violação inexiste pretensão a ser exigida. Consequentemente, inexistirá prazo prescricional. Com a violação, nasce um direito subjetivo à prestação e, partir deste cenário, surge a possibilidade de contagem do prazo da prescrição (DELGADO, 2019, p. 265). A prescrição, desse modo, recai sobre direitos prestacionais (ações condenatórias), diferentemente da decadência cujo objeto é um direito potestativo (ações constitutivas). (AMORIN FILHO, 2005, p. 763). Essa posição, entretanto, deve ser esclarecida. É possível a propositura de uma demanda cujo pedido seja uma tutela inibitória. Neste caso, inexistiria violação do direito

\footnotetext{
4 A palavra doutrina é utilizada a partir do latim docere (ensinar, instruir etc.) ou, de forma mais atualizada, como um conjunto de lições, teorias e intepretações expostas em livros de direito. (SILVA, 2009, p. 505).
} 
propriamente dito. Nem por isto inexistiria pretensão. (LEONARDO, 2010).

A prescrição, na perspectiva do direito civil, pode ser declarada de ofício. O art. 194 do CC, cujo texto impedia que o juiz a suprisse ex officio, foi revogado pela Lei n. 11.280/2006. Esta alteração modificou uma tradição do ordenamento jurídico nacional de exigir da parte, a quem a prescrição aproveitasse, a respectiva arguição. Isto se dava em razão da autonomia da vontade, cuja liberdade era conferida ao devedor, inclusive para deixar de arguí-la, e na possibilidade de renúncia (CC, art. 191). A prescrição, com isso, deixa de ser um direito individual e passa a ter uma conotação de ordem pública. (LÔBO, 2020).

No direito do trabalho, entretanto, o Tribunal Superior do Trabalho (TST) consolidou sua jurisprudência, em sede de julgamento no agravo em recurso de revista 1107-22.2017.5.12.0003, no sentido de ser incabível a declaração de ofício do prazo prescricional, sob o argumento de que, entendimento contrário, afrontaria o princípio da proteção, a partir de uma constatação de que a relação jurídica de emprego é marcada por um evidente desequilibro entre empregado e empregador. (BRASIL, 2020g).

O prazo prescricional, segundo art. 192 do CC, não pode ser alterado por acordo das partes. Os interregnos previstos para este fim, portanto, são os previstos legalmente. Entretanto, existem causas impeditivas, suspensivas e interruptivas do transcurso da prescrição. No CC, estão previstas nos arts. 197 a 204. Na CLT, de maneira assistemática, há causas deste tipo, como a consignada no art. $11, \S 4^{\circ}$, cujo teor admite a interrupção do prazo prescricional pela propositura da reclamação trabalhista, e a contemplada no art. 440, cujo texto impede a contagem do mencionado interregno em caso de menores de idade.

Parte da doutrina sinaliza que as hipóteses de impedimento, suspensão e interrupção do prazo prescricional consubstanciam enumeração taxativa. (MIRANDA, 2013, p. 317; WALD, 
CAVALCANTI; PAESANI, 2015; LÔBO, 2020). Silva afirma que a prescrição é matéria regulada por lei e jamais pode ser interpretada extensivamente ou por analogia. (2009, p. 1081).

Em tese, a partir dessas concepções teóricas, inexistiram outras hipóteses que não as previstas em lei. Esta posição parece adequada, mas deve ser interpretada a partir do texto constitucional e de instrumentos internacionais de direitos humanos garantidores do acesso à jurisdição, cujo efeito será a admissão, de maneira excepcional e plenamente justificada, desde que devidamente comprovada, de causa impeditiva, suspensiva ou interruptiva de acesso à jurisdição, ainda que não listada expressamente no rol do CC.

As causas de impedimento, de suspensão e de interrupção do CC devem ser submetidas a um filtro constitucional, sobretudo ao direito/garantia5 de acesso à jurisdição (CF/1988, art. $\left.5^{\circ}, \mathrm{XXXV}\right) . \mathrm{Na}$ condição de função estatal, descabe considerar a jurisdição como faculdade ou um poder discricionário, mas sim como dever do Estado. Nesta perspectiva, pode ser cogitada como dever fundamental do Estado. 6 Também se apresenta como direito fundamental, denominado direito de acesso de postular do Estado a tutela jurisdicional (direito de ação ou direito de acesso à jurisdição), cuja fruição se concretiza pela garantia fundamental do processo constitucional. O processo, enfim, se põe como uma garantia contra o exercício ilegítimo de funções públicas (NUNES, 2012. p. 209) e, concomitantemente, como maneira de exercício de direitos, inclusive fundamentais. Logo, qualquer óbice (e pouco importa a nomenclatura utilizada: obstáculo, impedimento etc.) ao legítimo exercício desse direito fundamental parece capaz de introduzir uma causa de impedimento, suspensão ou interrupção da contagem do prazo

5 É clássica a divisão entre direitos e garantias. Estas são direitos, embora, muitas vezes, salientem seu caráter instrumental de proteção de direitos (Cf. CANOTILHO. (2003, p. 396). A pesquisa não adota rigorismo acerca desta divisão.

${ }^{6}$ Acerca dos deveres fundamentais, Cf. Canotilho (2003, p. 531). 
prescricional. É neste sentido que as hipóteses do CC e da CLT devem ser analisadas.

Com essas ressalvas, Leal (1982, p. 165-166), ao analisar as causas de impedimento e suspensão da contagem do prazo prescricional previstas no CC (no caso, era o de 1916) se reporta a duas outras hipóteses desta natureza, aparentemente, extraídas do texto normativo, ou seja, ao interpretar o enunciado normativo encontrou duas normas jurídicas: obstáculos judicial e legal.

Delgado (2019, p. 265-266), a partir de uma abordagem vinculada ao direito do trabalho, concorda com a proposta. Barros (2005), por sua vez, reconhece que as causas preclusivas da prescrição, são taxativas. Entretanto, esta conclusão, a seu ver, não frustraria uma interpretação extensiva sobre as hipóteses previstas. Nesse cenário, pode-se introduzir os efeitos de uma pandemia, como a covid-19, na contagem do prazo prescricional.

A posição de Theodoro Júnior (2018, p. 115-116), aparentemente, se alinha às ideias defendidas por Leal (1982), Delgado (2019) e Barros (2005), ao advogar que, a princípio, não se deve admitir hipóteses ausentes da listagem promovida pelo CC, relativamente as causas impeditivas, suspensivas e interruptivas da contagem do prazo prescricional, contudo haveria um espaço, embora restrito, para alegação de justo impedimento.

As ideias de obstáculo e justo impedimento ao exercício do direito de acesso à jurisdição são fundamentais para se considerar se a pandemia poderia, ou não, impulsionar, o impedimento ou a suspensão da contagem do prazo da prescrição.

Formulado esse rápido apanhado sobre a prescrição. A partir dele e com outras teorias mais alinhadas ao direito do trabalho, buscar-se-á, na próxima seção, responder ao problema da pesquisa. 


\section{PRESCRIÇÃO, DIREITO DO TRABALHO E PANDEMIA}

A prescrição, malgrado se apresente como um único instituto, possui teorias, regras e princípios decorrentes de cada ramo jurídico no qual é aplicada. A CLT prevê regras sobre a prescrição, contudo são, evidentemente, insuficientes. Por corolário, há um consenso teórico no sentido de que os preceitos do CC devem ser importados para o direito do trabalho. A doutrina trabalhista, de maneira geral, ao abordar a prescrição no direito do trabalho, utiliza diversos dispositivos do CC (BARROS, 2005, p. 968-982; DELGADO, 2019, p. 256-268; LEITE, 2019, p. 736-737; CASSAR, 2018, p. 1224-1232; GARCIA, 2019, p. 1042; MORAES FILHO; MORAES, 2014, p. 187).

$\mathrm{O}$ art. $8^{\circ}, \S 1^{\circ}$, da CLT consubstanciou a técnica da subsidiariedade. Autoriza a importação do direito comum sempre que houver omissão no direito do trabalho. É algo presente no ordenamento jurídico trabalhista há muito tempo e também verificado no direito do trabalho de outros países. Em certa medida, há um reconhecimento de que a dogmática jurídica trabalhista é incompleta para acompanhar a dinâmica das relações de trabalho.

A Reforma Trabalhista retirou o requisito da compatibilidade (antes eram dois os requisitos: omissão e compatibilidade) do texto do art. $8^{\circ}$ da CLT. Mesmo a par desse novo dispositivo, parece necessário exigir a compatibilidade entre o texto importado e os princípios e as regras do direito do trabalho, por se tratar de uma exigência lógica e implícita. Parece inadequado admitir que basta a omissão, o que daria autorização para introduzir, no direito do trabalho, por exemplo, dispositivos do $\mathrm{CC}$ incompatíveis com a natureza das relações de emprego, cuja síntese seria, antes de soluções, a introdução de maiores problemáticas. Neste sentido, ao tratar da importação de preceptivos do direito processual civil para o direito processual do trabalho (os argumentos são bastante similares): 


\begin{abstract}
A história do direito e processo do trabalho e os seus compromissos assumidos ao longo da história, entrementes, permitem diferenciá-los do processo civil e resistir a essa pretensão. Aqueles ramos jurídicos vinculam-se aos pleitos de trabalhadores e sindicatos e consubstanciam conquistas sociais decorrentes de lutas de classes, malgrado suas contradições e conciliações com o modo de produzir capitalista. O processo civil, diferentemente, encontra outro eixo temático, o que, inclusive, motivaria a existência de ritos diferentes nesses dois ramos processuais. Seu objetivo é concretizar o direito civil, cujo centro se encontra a exaltação e manutenção da propriedade privada, e outros ramos jurídicos (como os direitos tributário e administrativo), que não possuem uma lógica processual específica. Logo, a importação, sem critérios, do texto do CPC para o processo do trabalho implicará modificação estrutural da defesa dos trabalhadores perante o Poder Judiciário e, consequentemente, (maior) prevalência da propriedade privada em detrimento dos direitos sociais. (FONSECA; LEITE, 2017).
\end{abstract}

Consequentemente, a posição teórica, assumida também neste artigo, de que o CC deve funcionar como fonte subsidiária relativamente à prescrição, se abstém de ocasionar o efeito imediato de aplicação indiscriminada, no direito do trabalho, de todos os dispositivos e de toda a hermenêutica civilista acerca do tema. Haverá, portanto, um filtro implícito de compatibilidade a ser previamente manejado, sob pena de afrontar a autonomia do direito do trabalho e carrear para as relações empregatícias disposições cabalmente incompatíveis.

A prescrição no direito do trabalho, ao longo do tempo, passou por grandes transformações.7 Alguns exemplos servem para demonstrar este contexto.

O Decreto n. 23.103/1933 (BRASIL, 1933), cujo texto regulamentava a concessão de férias aos empregados em estabelecimentos comerciais e bancários e em instituições de assistência privada, previa prescrição (do direito a férias) de um ano depois do seu período concessivo (art. 17). Um prazo, portanto, extremamente curto.

7 Sobre o tema, cf. Nascimento (2009, p. 340-342). 
O Decreto-Lei n. 1.237/1939 (BRASIL, 1940), cujo texto organizava a então nascente Justiça do Trabalho, ainda desvinculada do Poder Judiciário, previa o prazo de dois anos a título de prescrição (art. 101). O prazo era contado a partir do fato que deu origem à violação.

A CLT, na redação original do art. 11, previu prazo prescricional de dois anos, sem indicação de um marco inicial da contagem. As suas posteriores alterações, em razão da necessidade de adaptá-la ao texto constitucional, trouxeram inovações, como a extinção contratual como início da contagem do prazo e a prescrição quinquenal.

A previsão dos prazos prescricionais de pretensões trabalhistas na CF/1988 (art. $7^{\circ}$, XXIX), na condição de direitos fundamentais dos trabalhadores, encontra uma justificativa histórica. Comparada com os preceitos anteriores, houve um relativo avanço para os obreiros: prescrição quinquenal e o marco inicial a partir da extinção do contrato de emprego. Materializou-se, portanto, uma conquista histórica, parcialmente afastada pela Emenda Constitucional n. 28/2000, cuja promulgação introduziu a prescrição quinquenal (antes inexistia prazo limite) na pretensão trabalhista do empregado rural. Por isto, alguns autores consideram a previsão do art. $7^{\circ}$, XXIX, da CF/1988, como um autêntico direito constitucionalmente assegurado aos trabalhadores. (DONATO, 2008, p. 262).

$\mathrm{O}$ art. $7^{\circ}$ da $\mathrm{CF} / 1988$ consigna os direitos fundamentais dos trabalhadores. Esta, inclusive, é a posição do Supremo Tribunal Federal, consolidada na ação direita de inconstitucionalidade 5938, STF (BRASIL, 2019). O dispositivo, além de listar direitos, consigna, inusitadamente, a prescrição (art. $7^{0}$, XXIX). Apesar deste dado relevante, extraído da realidade histórico-social e da dogmática jurídica, a prescrição, em essência, não se apresenta como direito dos trabalhadores, por ser uma maneira de extinguir pretensões e tornar impossível a exigência de direitos trabalhistas, inclusive fundamentais. A sua positivação no rol de direitos fundamentais dos 
trabalhadores parece insuficiente para apagar esse traço, malgrado possua a função de criar um padrão constitucional mínimo cujo epílogo é a impossibilidade jurídica de redução do prazo, fixado a título de prescrição, pelo poder constituinte derivado.

O preceito acerca da prescrição no direito do trabalho é bastante contraditório. Sob o ponto de vista dogmático, parece inquestionável. Contudo quando analisado em uma perspectiva teórica-crítica, sua conotação é bastante diferente da percepção civilista, o que obriga o intérprete a buscar outras sendas hermenêuticas.

Os direitos decorrentes e descumpridos de uma relação de trabalho não se equiparam a um mero liame creditício. Nas palavras de Maior (2011, p. 761), “[...] Não é um mero 'inadimplemento contratual', como a lógica liberal [...] faz supor. Trata-se de um ato ilícito que não repercute apenas na esfera individual do trabalhador, mas também em toda a sociedade [...]”.

Severo (2017, p. 101 e 103) igualmente enxerga, com reservas, a prescrição nas relações de trabalho. Segundo esta autora, a prescrição é adequada à preservação do capital. Logo, é estruturada em uma relação de crédito e débito. Foram preferidas as garantias do sujeito proprietário em detrimento da realização do Estado social.

Santos (2016), em certa medida, enxerga o regimento prescricional, no direito do trabalho, como algo incompatível as noções extraídas do princípio da proteção.

A lição de Viana (2008, p. 163) acerca do tema é clássica:

[...] O legislador - pensei - é como aquele mágico. Quando quer, faz o direito sumir na cartola, ou o transforma num inofensivo coelho. Mistura e confunde realidade e fantasia, trocando a essência pela aparência. Com a sua mágica, ele também recebe, de certo modo, um pagamento. Mostra à sociedade, ainda uma vez, que 'o direito não socorre os que dormem', e com isso mantém os empresários mais ou menos satisfeitos, os trabalhadores mais ou menos submissos e o sistema ainda mais forte. [...] 
Na linha do exposto por Viana (2008), a prescrição, no direito do trabalho, cumpre o papel de esconder, pela aparência, uma lamentável realidade de sonegação de direitos sociais (leia-se: direitos fundamentais). As lições de Maior (2011), Severo (2017) e Santos (2016) patenteiam a incompatibilidade do instituto com as relações empregatícias.

Nascimento (2009, p. 339-340), por seu turno, alerta que a prescrição, aplicada às relações de emprego, é bastante problemática, sobretudo quando há contagem do prazo prescricional durante a vigência do contrato no qual o empregado é a parte subordinada. Certamente, haverá uma tendência (involuntária) à inércia, diante do temor, por parte do empregado, de perder seu emprego, caso manifeste sua pretensão de exigir seus direitos.

Cueva (1969, p. 887) igualmente reconhece os problemas advindos da aplicação da prescrição às relações de trabalho. A prescrição é um meio de o empregador se libertar de suas obrigações, porém, no fundo, para o aludido autor, possui natureza de renúncia a direitos, sobretudo quando se lembra que, no Brasil, a prescrição quinquenal incide quando vigente a relação empregatícia.

A violação de um direito trabalhista (este ato faz nascer a contagem do prazo prescricional), além da afronta jurídica propriamente dita, consubstancia uma desvalorização do trabalho humano e sua reiteração gera dano à sociedade. (MONTENEGRO; FERRAZ; VILLATORE, 2019, p. 79-80). É neste contexto que a prescrição trabalhista deve ser analisada.

Os direitos fundamentais trabalhistas são direitos garantidores da vida material dos trabalhadores (maioria da população). A prescrição, portanto, integra um dos elementos capazes de dificultar este escopo. Logo, no direito do trabalho a concretização da prescrição deve ser interpretada de maneira restritiva, sob pena de inviabilizar a concretização de direitos sociais, cuja existência não pode ser confundida com uma mera relação creditícia. 
No direito do trabalho, além dos prazos bienal e prescricional previstos, na CF/1988 e na CLT, a título de prescrição, há ainda, no plano legal, a previsão de períodos de tempo prescricionais parcial e total. Estas espécies foram criadas pela jurisprudência do TST. A Reforma Trabalhista, todavia, inseriu o $§ 2^{\circ}$ no art. 11 da CLT e, com isto, os prazos de prescrição total e parcial, passaram a ser previstos no plano legal (e não apenas pela jurisprudência).

Além dos prazos de prescrição bienal, quinquenal, total e parcial, há, no direito do trabalho, a prescrição intercorrente. Inexistia uma previsão específica no texto da CLT até a Reforma Trabalhista. Esta, entrementes, inseriu o art. 11-A na CLT, cujo texto passou a prevê-la expressamente.

Malgrado a particularidade do direito do trabalho no qual, como visto, há diversos tipos prescricionais (bienal, quinquenal, total, parcial e intercorrente), as considerações sobre interrupção, suspensão e impedimento do prazo de prescrição valem para todos as espécies e não apenas para bienal. O TST, no E-ED-RR 1980017.2004.5.05.0161, aparentemente neste caminho, decidiu que a causa interruptiva gera efeitos nas prescrições bienal e quinquenal (BRASIL, 2012), o que, talvez, possa ser aplicado também em outras situações.

Colocada essas questões, parece possível enfrentar diretamente o problema da pesquisa e concluir, ainda que provisoriamente, se pandemias, como a gerada pelo vírus Sars-CoV2, possuem o condão de impedir ou suspender a contagem do prazo prescricional.

Cumpre lembrar que causas que impedem e suspendem a contagem do prazo prescricional, geralmente, materializam fatos ocorridos independentemente da explícita vontade da parte beneficiada As causas interruptivas, diferentemente, a rigor, decorrem de explícita ação da parte beneficiada (DELGADO, 2019, p. 262 e 263). A pandemia, portanto, caso seja a hipótese, enquadrar-se-ia como um causa impeditiva ou suspensiva da contagem do prazo prescricional. 
Aparentemente, o texto do CC não contempla que pandemias impedem ou suspendem a contagem do prazo prescricional, todavia, ainda que excepcionalmente, parece possível, a partir dos enunciados normativos, encontrar alternativas. Entretanto, como bem ressaltado por Pamplona Filho e Fernandes, essas hipóteses são situações de crise da fluência do prazo prescricional (2018) e como tais devem ser interpretadas.

Leonardo esclarece que o CC de 2002 perdeu oportunidade de contemplar causas de impedimento do prazo de prescrição em moldes mais abertos para certos contextos de grave vulnerabilidade (2010). Essa observação se amolda perfeitamente à situação gerada pela pandemia gerada pelo vírus Sars-CoV-2. A invisibilidade social, que "[...] teima em continuar" (MORAIS; MOREIRA, 2019) parece incapaz de ocultar uma pandemia dessa magnitude e seus efeitos, sobretudo, em partes vulneráveis como os trabalhadores.

O cenário, entretanto, é bastante problemático. O neoliberalismo e o movimento reformista no direito do trabalho no país, ao menos nessa quadra histórica, tendem a encurtar direitos. A Reforma Trabalhista, ocorrida no Brasil em 2017, é um exemplo de evidente retrocesso social. (VALENTE; FOGAÇA; SILVA, 2018). Positivar o impedimento e a suspensão da contagem do prazo prescricional de pretensões trabalhistas em casos de pandemia, sinalizaria para aumento da proteção de direitos dos trabalhadores, o que significaria algo fora da tendência de flexibilização, desregulamentação e retrocesso.

A prática do direito consiste em argumentar (ATIENZA, 2016, p. 1). Sua materialização dar-se pela linguagem, sobretudo a escrita. Por efeito, os textos normativos, por se manifestarem sob a forma de um tipo de linguagem (textual), ${ }^{8}$ por mais completos que parecem ser, sempre darão margem a uma vagueza, a uma ambiguidade e uma textura aberta; algo inato e inafastável da linguagem. O texto deverá 
ser filtrado pela linguagem pragmática, isto é, aquela cuja amplitude avança sobre as fases anteriores da linguagem (sintática e semântica) para incluir a relação dos sinais com os sujeitos e com o uso (HERRERO, 2009, p. 166; WARAT, 1994, p. 126)9 que algo é apresentado (GADAMER, 2004, p. 16 e 497).

Uma das consequências deste reconhecimento é a de que o enunciado normativo (ou texto normativo) é inconfundível com a norma jurídica (MÜLLER, 2004, p. 53). Esta decorre daquele e é o seu significado, depois do processo interpretativo (ALEXY, 2008, p. 53 e 54). Em outro dizer, o texto é a matéria-prima do sistema jurídico (MACCORMICK, 2008, p. 32). A generalização do texto normativo, portanto, não permite um prévio posicionamento sobre todas as futuras possibilidades de aplicação. Será imprescindível trabalho interpretativo-construtivo de buscar o mais convincente argumento, obviamente amparado pelo Direito e a partir das circunstâncias do caso analisado, com a consideração de que, como evento histórico, a causa apreciada é única e irrepetível (COURA; FONSECA, 2015, p. 112).

O reconhecimento do direito como linguagem e a vagueza, a incompletude e a maleabilidade inerente a esta, todavia, inadmitem a discricionariedade interpretativa. Cabe interpretá-lo a partir do texto normativo e dos seus lindes semânticos e sintáticos. Este é um ponto de partida obrigatório, sob pena de afronta a legalidade ínsita ao sistema jurídico, negar o Estado democrático de direito e tornar arbitrária a função deontológica do Direito. Há, portanto, lindes também acerca da coerência e integridade, além de outros limites normativos, como, por exemplo, a observância de conflitos legislativos e as interpretações com efeitos vinculantes.

Diante do quadro caótico desencadeado pelo aumento de infecções e de mortes pelo vírus Sars-CoV-2, houve restrição de atividades, inclusive produtivas, e incentivo ao distanciamento social e ao confinamento domiciliar. As pessoas integrantes dos 
denominados grupos de riscos, por serem mais suscetíveis aos efeitos da doença, receberam a recomendação de manterem máximo isolamento e redobrada atenção.

$\mathrm{O}$ art. $6^{\circ}$-C da Lei n. 13.979/2020, um dos atos promulgados para combater a pandemia decorrente da Covid-19, suspendeu os prazos processuais em desfavor dos acusados e entes privados processados em processos administrativos enquanto perdurar o estado de calamidade de que trata o Decreto Legislativo n. 6, de 2020. O Parágrafo único, por seu turno, suspendeu o transcurso dos prazos prescricionais para aplicação de sanções administrativas a servidores e empregados públicos. $\mathrm{O}$ art. $6^{\circ}-\mathrm{D}$, por fim, suspendeu o transcurso dos prazos prescricionais para aplicação de sanções administrativas previstas em outros atos normativos. Portanto, em nenhum de seus dispositivos, houve determinação para suspensão da contagem do prazo prescricional.

O CNJ, por sua vez, editou Resoluções para tratar do funcionamento do Poder Judiciário no período pandêmico. A Resolução n. 313/2020 (BRASIL, 2020h) estabeleceu restrições ao trabalho presencial no Poder Judiciário e suspendeu os prazos processuais até 30 de junho 2020 (art. $5^{\circ}$ ), todavia, garantiu a continuidade dos serviços mínimos, como a distribuição de processos e o atendimento de advogados, defensores públicos e membros do Ministério Público (art. $2^{\mathrm{o}}, \S 2^{\circ}$ ). Por fim, a precitada Resolução assegurou que a suspensão de prazos processuais não impedia a prática de ato processual necessário à preservação de direitos e de natureza urgência (art. $5^{\circ}$, parágrafo único).

A Resolução n. 314/2020 do CNJ (BRASIL, 2020i) prorrogou, até 15 de maio de 2020, o prazo de vigência da Resolução n. 313/2020 (art. $1^{\circ}$ ), todavia, determinou a retomada dos prazos dos processos eletrônicos a partir de 4 de maio de 2020 (art. $3^{\circ}$ ). A mencionada Resolução admitiu que, mesmo nos processos eletrônicos, haja a possibilidade de a parte justificar a impossibilidade de realização do ato. Neste caso, depois de decisão fundamentada do Juízo, poderá ser adiado (art. $\left.3^{\circ}, \S 2^{\circ}\right)$. 
A Resolução n. 318/2020 do CNJ (BRASIL, 2020j), novamente, prorrogou o prazo, agora para 31 de maio de 2020 (art. $\left.1^{0}\right)$. Posteriormente, houve nova prorrogação até 14 de junho de 2020 pela Portaria n. 79/2020, também do CNJ. (BRASIL, 2020k).

A Resolução n. 322/2020 do CNJ (BRASIL, 2020l), por se turno, estabeleceu, no âmbito do Poder Judiciário, medidas para retomada dos serviços presenciais a partir de 15 de junho de 2020, com o afastamento da suspensão dos prazos processuais. Na hipótese de manutenção do regime especial de trabalho, estabelecido pela Resolução n. 314/2020, haverá apenas manutenção da suspensão do prazo processual dos processos físicos. Por fim, na situação de lockdown, ocorrerá a suspensão de todos os prazos processuais - em autos físicos e eletrônicos (art. $3^{\circ}$ ).

A Medida Provisória n. 927/2020, atualmente revogada, cujo texto também dispunha sobre as medidas trabalhistas para enfrentamento do estado pandêmico decorrente da covid-19. Em uma de suas previsões (art. $1^{0}$, parágrafo único), para os fins do direito do trabalho, reconheceu estado de força maior, entretanto, nada dispôs sobre a suspensão, ou não, dos prazos prescricionais de pretensões trabalhistas.

Posteriormente, a Lei n. 14.010/2020, cujo texto dispõe sobre o regime jurídico emergencial e transitório das relações jurídicas de direito privado no período da pandemia, previu um capítulo sobre prescrição e decadência:

\footnotetext{
CAPÍTULO II

DA PRESCRIÇÃO E DECADÊNCIA

Art. $3^{\circ}$. Os prazos prescricionais consideram-se impedidos ou suspensos, conforme o caso, a partir da entrada em vigor desta Lei até 30 de outubro de 2020. $\S 1^{\circ}$. Este artigo não se aplica enquanto perdurarem as hipóteses específicas de impedimento, suspensão e interrupção dos prazos prescricionais previstas no ordenamento jurídico nacional.

$\S 2^{\circ}$. Este artigo aplica-se à decadência, conforme ressalva prevista no art. 207 da Lei $\mathrm{n}^{0} 10.406$, de 10 de janeiro de 2002 (Código Civil) (BRASIL, 2020d).
} 
A sobredita lei foi impositiva quanto ao impedimento ou à suspensão da contagem do prazo de prescrição. Sua epígrafe é no sentido de que seus termos se aplicam às relações jurídicas decorrentes do direito privado. Ao considerar que o direito do trabalho, ao menos para a posição majoritária da doutrina, possui natureza jurídica de direito privado (DELGADO, 2019, p. 76; CASSAR, 2018, p. 10; LEITE, 2019, p. 49), o dispositivo aplicar-se-ia às relações de trabalho (sobretudo na de emprego). Logo, entre 12 de junho a 30 de outubro de 2020 ocorreria o impedimento ou a suspensão da contagem prazo prescricional da pretensão trabalhista.

Esta lei parece seguir uma diretriz verificada em outros países. Por exemplo, em Portugal, a Lei n. 4-A/2020 (PORTUGAL, 2020), procedeu a primeira alteração da Lei n. 1-A/202, cujo texto aprova medidas excecionais e temporárias de resposta à situação epidemiológica provocada pelo vírus SARS-CoV-2, e à segunda alteração ao Decreto-Lei n. 10-A/2020, de 13 de março, cujo texto estabelece medidas excecionais e temporárias relativas à situação epidemiológica do novo coronavírus.

A Lei n. 4-A/2020, todavia, não alterou o teor dos números 3 ("3 - A situação excecional constitui igualmente causa de suspensão dos prazos de prescrição e de caducidade relativos a todos os tipos de processos e procedimentos.") e 4 ("4 - O disposto no número anterior prevalece sobre quaisquer regimes que estabeleçam prazos máximos imperativos de prescrição ou caducidade, sendo os mesmos alargados pelo período de tempo em que vigorar a situação excecional.”) do art. $7^{\circ}$ (prazos e diligências) da Lei n. 1-A/2020, cujo texto consagrou a suspensão dos prazos de prescrição e de caducidade concernentes aos vários tipos de processos e procedimentos, tendo prevalência relativamente aos regimes que determinem prazos máximos imperativos de prescrição ou caducidade. Esses prazos são estendidos pelo período de tempo em que estiver em vigor a situação excecional da pandemia.

Ainda em Portugal, o art. 321, 1, do Código Civil prevê suspensão do prazo prescricional por motivo de força maior: "Artigo 
$321 .^{\circ}[. .]$.1 . A prescrição suspende-se durante o tempo em que o estiver impedido de fazer valer o seu direito, por motivo de força maior, no decurso dos três meses do prazo.” (PORTUGAL, 2019).

Esse ponto é importante. O art. $8^{\circ}$ da CLT autoriza que o juiz do trabalho, à falta de disposições legais e contratuais aplicáveis ao caso, aplique o direito comparado. No plano da legalidade, portanto, é admissível que seja utilizada, por exemplo, preceitos de outros ordenamentos jurídicos, como o Código Civil português, cujo aludido dispositivo admite a suspensão da prescrição em hipóteses caracterizadas como força maior, condição verificada com a pandemia da covid-19.

A Lei n. 14.010/2020, contudo, se absteve de equacionar a controvérsia por inteiro, por não contemplar o período anterior à sua vigência (março a junho de 2020), bem como supor que em 30 de outubro de 2020 a pandemia terá cessado. O Brasil já vivia, neste período (março a junho de 2020), a pandemia e inexiste evidencia científica de que ela cessará a partir de novembro deste ano. Consequentemente, há dúvida acerca do impedimento ou da suspensão da contagem do prazo prescricional.

Necessário, nesse ponto, volver às teses de Leal (1982) e Theodoro Júnior (2018), aparentemente adotadas por Delgado (2019) e Barros (2005), bem como (e sobretudo) a uma interpretação constitucional a partir do direito-garantia fundamental de acesso à jurisdição. Pandemias, a partir do exemplo da covid-19, certamente, podem funcionar como um obstáculo ou um justo impedimento ao exercício de uma pretensão trabalhista, isto é, podem dificultar o acesso à jurisdição. Pode-se imaginar, a título de exemplo: o contágio pela doença; o fechamento de fóruns; a suspensão de atividades dos escritórios de advocacia e dos sindicatos profissionais (prestadores do serviço de assistência judiciária gratuita aos trabalhadores); as restrições a deslocamentos; as dificuldades de acesso a documentos e a internet etc. Essas supostas situações são capazes de impedir a propositura da demanda perante o Poder Judiciário trabalhista. 
Alguns destes acontecimentos (entre outros similares) podem ter ocorrido durante o período compreendido entre março a junho de 2020 (considerando que a Lei n. 14.010/2020 teria equacionado a controvérsia somente no período compreendido entre 12 de junho a 30 de outubro de 2020).

Um dado relevante é a suspensão dos prazos processuais imposta pelo CNJ. Há duas situações diferentes: processos físicos e processos eletrônicos. Na Justiça do Trabalho, a rigor, os processos são eletrônicos e o sistema de distribuição de demandas igualmente é realizado eletronicamente. As Resoluções do CNJ promoveram esta diferenciação e mantiveram a suspensão processual para os processos físicos. Desde de 4 de maio de 2020, houve a retomada dos prazos nos processos eletrônicos. Por corolário, a Resolução n. 313 do CNJ, publicada em 19 de março de 2020, para os processos eletrônicos, geraria efeitos até 4 de maio de 2020, salvo se houver comprovação, pela parte, da impossibilidade de exercitar sua pretensão ou praticar algum outro ato processual.

Para ser mais exato, na hipótese de o último dia do prazo prescricional ocorrer em dia não útil (o que também contempla o período de suspensão processual, bem como as situações caracterizadas como obstáculo ou justo impedimento), o prazo é prorrogado para o dia útil seguinte (BARROS, 2005, p. 986; DONATO, 2008, p. 264; CASSAR, 2018, p. 1233-1234). O art. 132, $\S 1^{\circ}$, do CC é expresso ao preceituar: "[...] Se o dia do vencimento cair em feriado, considerar-se-á prorrogado o prazo até o seguinte dia útil.” O TST outrossim, no recurso de revista 68906075.2000.5.02.5555, possui posição neste sentido. (BRASIL, 2004).

Operação mais complexa é a aplicar este raciocínio ao marco inicial da contagem do prazo prescricional, ou seja, se o primeiro dia da contagem for um dia não útil (o que também contemplaria o período de suspensão processual, bem como as situações caracterizadas como obstáculo ou justo impedimento) haveria um impedimento ao início da contagem do prazo, como ocorre com os interregnos de natureza processual? Em razão da previsão da Lei n. 
810/1949 (BRASIL, 1949) e do art. 132, $3^{\circ}$, do CC, cujos textos preceituam que a contagem dos prazos em anos deve considerar o dia do início ao dia e mês correspondentes do ano seguinte, haveria dificuldade em afirmar positivamente.

Caso seja ultrapassada esta barreira, durante o período da pandemia, agregado a outras condições que impeçam o exercício de uma pretensão, haveria um impedimento ou um obstáculo ao início da contagem do prazo prescricional. A Lei n. 14.010/2020 parece seguir esta linha ao aludir tanto ao impedimento quanto à suspensão da contagem do prazo.

A partir do caso da pandemia do vírus SARS-CoV-2 e antes da promulgação da Lei n. 14.010/2020, há posição teórica no sentido de que o prazo da prescrição de pretensão trabalhista, a rigor, não foi suspenso, salvo demonstração de justo impedimento capaz de demonstrar o livre acesso à jurisdição (FREITAS, 2020, p. 310), bem como a de que inexistiria hipótese de suspensão ou impedimento da contagem do prazo prescricional, por estar ausente da lei, inclusive dos recentes atos normativos editados, e pelo fato de a Justiça do Trabalho disponibilizar acesso à jurisdição pelo processo eletrônico, cuja funcionalidade sem mantém durante todo o período pandêmico (MOLINA, 2020).

A regra geral parece ser a de ausência de impedimento ou suspensão da contagem do prazo prescricional em um momento de pandemia. Esta posição, contudo, não impedirá a demonstração, no caso concreto, da existência de obstáculo justificador da adoção da exceção, até porque, como alertado, o texto normativo infraconstitucional deve ser interpretado a partir da $\mathrm{CF} / 1988$ e não deve ser confundido com a norma jurídica.

Consequentemente, parece que, na situação de pandemia, pode ser aplicado, por analogia, o entendimento divulgado pelo TST na Orientação Jurisprudencial (OJ) n. 375 da Seção de Dissídios Individuais 1 (SDI-1) (BRASIL, 2020m): 


\begin{abstract}
OJ-SDI1-375 AUXÍLIO-DOENÇA. APOSENTADORIA POR INVALIDEZ. SUSPENSÃO DO CONTRATO DE TRABALHO. PRESCRIÇÃO. CONTAGEM (DEJT divulgado em 19, 20 e 22.04.2010). A SUSPENSÃO DO CONTRATO DE TRABALHO, EM VIRTUDE DA PERCEPÇÃO DO AUXÍLIO-DOENÇA OU DA APOSENTADORIA POR INVALIDEZ, NÃO IMPEDE A FLUÊNCIA DA PRESCRIÇÃO QUINQUENAL, RESSALVADA A HIPÓTESE DE ABSOLUTA IMPOSSIBILIDADE DE ACESSO AO JUDICIÁRIO. (grifos no original)
\end{abstract}

A OJ n. 375 da SDI-1 do TST rechaçou a proposta de dupla suspensão, ou seja, a suspensão contratual ensejaria automaticamente a suspensão da contagem do prazo de prescrição. Segundo o verbete, a suspensão do contrato de emprego, em virtude de auxílio-doença ou da aposentadoria por invalidez, como regra, não impede a fluência do prazo prescricional. No entanto há uma ressalva: comprovação de absoluta impossibilidade de acesso ao Poder Judiciário.

Talvez, o mesmo entendimento possa ser aplicado para períodos de pandemia. Como regra, por se tratar, no Brasil, de processos eletrônicos, inexistiria impedimento ou suspensão do prazo prescricional, salvo se houver comprovação de absoluta impossibilidade de acesso ao Poder Judiciário, a partir de uma leitura constitucional das hipóteses de impedimento e suspensão do prazo prescricional e do parâmetro de que a prescrição, no direito do trabalho, fulmina direitos sociais e que, portanto, deve ser interpretada restritivamente, algo que deve ser considerado para fins de demonstração de obstáculo ou justo impedimento de acesso à jurisdição.

Por fim, cabe lembrar que admitir a incidência da prescrição em casos nos quais a inércia decorreu do contexto pandêmico é negar efetividade ao direito do trabalho e aos direitos fundamentais dos trabalhadores, algo muito comum nesse ramo jurídico. ${ }^{10}$

\footnotetext{
${ }^{10}$ São comuns investigações sobre a efetividade das normas trabalhistas. A título de exemplo: Ávila, Silva e Grokskreutz, cujo texto objetivou analisar a efetividade das normas ambientais trabalhistas para refugiados. (2020).
} 


\section{CONSIDERAÇÕES FINAIS}

Este artigo teve como problema analisar se uma pandemia, como a gerada pelo vírus Sars-CoV-2 (coronavírus), possui o condão de impedir ou suspender a contagem do prazo da prescrição de pretensões trabalhistas. A pesquisa partiu de uma hipótese afirmativa. A pandemia gerada pelo vírus Sars-CoV-2 (coronavírus) foi utilizada como exemplo. Entretanto o resultado da análise poderá ser manejado em outras situações excepcionais como a vivenciada atualmente.

Esta pesquisa se justificou em decorrência de polêmicas teóricas surgidas em torno da situação do prazo prescricional no direito do trabalho neste período pandêmico, o que, em última análise, gerou insegurança jurídica e o risco de fulminar direitos sociais dos trabalhadores.

Até a Lei n. 14.010/2020, inexistia um ato normativo referente à situação da prescrição na pandemia. Esta Lei previu que os prazos prescricionais estão impedidos ou suspensos pelo período compreendido entre 12 de junho a 30 de outubro de 2020. Entretanto se omitiu em equacionar a contagem da prescrição antes de junho e supôs que a pandemia se encerrará a partir do mês de novembro deste ano. Em última análise, a Lei n. 14.010/2020, apesar de sinalizar um caminho, foi incapaz de resolver, por completo, a controvérsia.

A pesquisa, a partir da abordagem dialética e da técnica pesquisa documental indireta nas modalidades pesquisas documental e bibliográfica, concluiu que, geralmente, as hipóteses de impedimento, de interrupção e de suspensão da contagem do prazo prescricional, previstas no CC, são aplicáveis ao direito do trabalho. Para tanto, dependem de uma leitura constitucional pautada no direito/garantia de acesso à tutela jurisdicional e adequada às 
particularidades do direito do trabalho, sob pena de colocar em risco a existência dos direitos fundamentais dos trabalhadores.

A par dessas constatações, pandemias, como a gerada pelo vírus Sars-CoV-2 (coronavírus), podem gerar o impedimento ou a suspensão da contagem do prazo prescricional de pretensões trabalhistas, caso haja comprovação de obstáculo ou justo impedimento de acesso à jurisdição, algo confirmado, em parte, pela Lei n. 14.010, de 10 de junho de 2020, cujo texto foi incapaz de resolver todas as polêmicas em torno do tema.

Uma das alternativas, além da leitura constitucional desse cenário e a partir das particularidades do direito do trabalho, é aplicar, por analogia, a OJ n. 375 da SDI-1 do TST e admitir que a parte corrobore a impossibilidade de acesso à jurisdição, o que justificaria o impedimento ou a suspensão da contagem do prazo prescricional. Esta possibilidade, ademais, se compatibiliza com o princípio da proteção do direito do trabalho e com as restrições ao regime da prescrição nesse ramo jurídico.

Outra possibilidade é aplicar o direito comparado, algo autorizado pelo art. $8^{\circ}$, caput, da CLT. À falta de disposições legais e contratuais, o juiz do trabalho pode aplicar preceptivos de ordenamentos jurídicos estrangeiros. O uso do Código Civil português é um exemplo cujo texto preceitua a suspensão do prazo prescricional na hipótese de força maior.

$\mathrm{O}$ rol alusivo ao impedimento, à suspensão e à interrupção do prazo prescricional previsto no CC e aplicável ao direito do trabalho, portanto, deve ser interpretado à luz da realidade vivenciada. A princípio, é exaustivo. Contudo, em situações de anormalidade cujo epílogo pode ser a impossibilidade de acesso à jurisdição, deve ser elastecido para impedir a concretização da prescrição da pretensão de direitos dos trabalhistas, sob pena de contribuir para inefetividade dos direitos sociais.

A pandemia pode funcionar com vetor para iniciação de processo legislativo (fonte material do direito do trabalho) cujo escopo seja o de positivar, no ordenamento jurídico brasileiro, preceito normativo cujo 
texto impeça o início e a continuidade do prazo prescricional de pretensões direitos trabalhistas em situações de excepcionalidade, como a vivenciada atualmente, sob pena de negar efetividade o direito do trabalho e os direitos fundamentais dos trabalhadores.

Data de Submissão: 15/06/2020

Data de Aprovação: 27/08/2020

Processo de Avaliação: double blind peer review

Editor Geral: Jailton Macena de Araújo

Editor de Área: Jailton Macena de Araújo

Assistente Editorial: Jaime Waine Rodrigues Mangueira

\section{REFERÊNCIAS}

\section{ADEODATO, João Maurício. Uma teoria retórica da norma jurídica e do direito subjetivo. São Paulo: Noeses, 2011.}

ALEXY, Robert. Teoria dos direitos fundamentais. Tradução Virgílio Afonso da Silva. São Paulo: Malheiros, 2008.

AMORIN FILHO, Agnelo. Critério científico para distinguir a prescrição da decadência e para identificar as pretensões imprescritíveis. In: Revista dos Tribunais, São Paulo, ano 94, v. 836, jun. 2005, p. 733-763.

ATIENZA, Manuel. As razões do direito: teoria da argumentação jurídica. 2. ed. Tradução Maria Cristina Guimarães Cupertino. Rio de Janeiro: Forense Universitária, 2016.

ÁVILA, Gustavo Noronha de; SILVA, Leda Maria Messias da; GROKSKREUTZ, Hugo Rogério. Da personalidade ao trabalho: um estudo sobre o ambiente laborativo dos Refugiados no Brasil e a 
efetividade das normas. Revista Prima@Facie, João Pessoa, v. 19, n. 41, maio-ago., 2020, p. 96-136. Disponível em:

https://periodicos.ufpb.br/index.php/primafacie/article/view/4876 3/30433. Acesso em: 19 ago. 2020.

AZEVEDO, Álvaro Villaça. Curso de direito civil. Teoria geral do direito civil. 2. ed. São Paulo: Saraiva Educação, 2019. v. I. E-book.

BARROS, Alice Monteiro. Curso de direito do trabalho. São Paulo: LTr, 2005.

BRASIL. [Constituição (1988)]. Constituição da República Federativa do Brasil de 1988. Brasília, DF: Presidência da República, [2019]. Disponível em:

http://www.planalto.gov.br/ccivil 03/Constituicao/Constituicao.ht m. Acesso em: 21 abr. 2020.

BRASIL. Decreto n. 23.103, de 19 de agosto de 1933. Regula a concessão de férias aos empregados em estabelecimentos comerciais e bancários e em instituições de assistência privada. Brasília, DF:

Presidência da República, [1933]. Disponível em:

https://www2.camara.leg.br/legin/fed/decret/1930-1939/decreto23103-19-agosto-1933-526803-publicacaooriginal-1-pe.html. Acesso em: 12 jun. 2020.

BRASIL. Decreto-Lei n. 1.237, de 2 de maio de 1939. Organiza a Justiça do Trabalho. Brasília, DF: Presidência da República, [1940]. Disponível em: http://www.planalto.gov.br/ccivil 03/decretolei/1937-1946/Del1237.htm. Acesso em: 6 jun. 2016.

BRASIL. Decreto-Lei n. 5.452, de $1^{\circ}$ de maio de 1943. Aprova a Consolidação das Leis do Trabalho. Brasília, DF: Presidência da República, [2020f]. Disponível em:

http://www.planalto.gov.br/ccivil 03/Decreto-Lei/Del5452.htm.

Acesso em: 21 abr. 2020.

BRASIL. Lei n. 10.406, de 10 de janeiro de 2002. Institui o Código Civil. Brasília, DF: Presidência da República, [2020e]. Disponível em:

https://www.planalto.gov.br/ccivil 03/LEIS/2002/L10406.htm. Acesso em: 28 maio 2020.

BRASIL. Lei n. 13.467, de 13 de julho de 2017. Reforma Trabalhista. Brasília, DF: Presidência da República, [2017]. Disponível em: http://www.planalto.gov.br/ccivil 03/ ato20152018/2017/lei/L13467.htm. Acesso em: 19 nov. 2017.

BRASIL. Lei n. 13.979, de 6 de fevereiro de 2020. Dispõe sobre as medidas para enfrentamento da emergência de saúde pública de importância internacional decorrente do coronavírus responsável pelo surto de 2019. Brasília, DF: Presidência da República, [2020b]. 
Disponível em: http://www.planalto.gov.br/ccivil 03/ ato20192022/2020/lei/L13979.htm. Acesso em: 21 abr. 2020.

BRASIL. Lei n. 14.010, de 10 de junho de 2020. Dispõe sobre o Regime Jurídico Emergencial e Transitório das relações jurídicas de Direito Privado (RJET) no período da pandemia do coronavírus (Covid-19). Brasília, DF: Presidência da República, [2020d]. Disponível em: http://www.planalto.gov.br/ccivil 03/ Ato20192022/2020/Lei/L14010.htm. Acesso em: 12 jun. 2020.

BRASIL. Lei n. 3.071, de $1^{\circ}$ de janeiro de 1916. Código Civil dos Estados Unidos do Brasil. Brasília, DF: Presidência da República, [1972]. Disponível em:

http://www.planalto.gov.br/ccivil 03/leis/L3071.htm. Acesso em: 10 jun. 2020.

BRASIL. Lei n. 81o, de 6 de setembro de 1949. Define o ano civil. Brasília, DF: Presidência da República, [1949]. Disponível em: http://www.planalto.gov.br/ccivil_03/leis/1930-1949/181049.htm\#: :text=LEI\%20No\%20810\%2C\%20DE,m\%C3\%AAs\%20cor respondentes\%20do\%20ano\%20seguinte. Acesso em: 12 jun. 2020.

BRASIL. Medida provisória n. 927, de 22 de março de 2020. Dispõe sobre as medidas trabalhistas para enfrentamento do estado de calamidade pública reconhecido pelo Decreto Legislativo $\mathrm{n}^{\circ} 6$, de 20 de março de 2020, e da emergência de saúde pública de importância internacional decorrente do coronavírus (covid-19), e dá outras providências. Brasília, DF: Presidência da República, 2020c. Disponível em: http://www.planalto.gov.br/ccivil 03/ ato20192022/2020/Mpv/mpvg27.htm. Acesso em: 9 maio 2020.

BRASIL. Ministério da Saúde. Coronavírus (covid-19). Dados do setor. Brasília, 2020a. Disponível em: https://coronavirus.saude.gov.br/sobre-a-doenca\# 0-que-e-covid. Acesso em: 21 abr. 2020.

BRASIL. Portaria n. 79, de 22 de maio de 2020, do Conselho Nacional de Justiça. Prorroga o prazo de vigência das Resoluções CNJ no 313/2020, no 314/2020 e no 318/2020. Brasília, DF: DJe/CNJ n. 150/2020, p. 2, 2020k. Disponível em: https://atos.cnj.jus.br/atos/detalhar/3326. Acesso em: 6 jun. 2020.

BRASIL. Resolução n. 313, de 19 de março de 202o, do Conselho Nacional de Justiça. Estabelece, no âmbito do Poder Judiciário, regime de Plantão Extraordinário, para uniformizar o funcionamento dos serviços judiciários, com o objetivo de prevenir o contágio pelo novo Coronavírus - Covid-19, e garantir o acesso à justiça neste período emergencial. Brasília, DF: DJe/CNJ n. 71/2020, p. 3-5, 2020h. Disponível em:

https://atos.cnj.jus.br/atos/detalhar/3249. Acesso em: 6 jun. 2020. 
BRASIL. Resolução n. 314, de 20 de abril de 2020, do Conselho Nacional de Justiça. Prorroga, no âmbito do Poder Judiciário, em parte, o regime instituído pela Resolução n ${ }^{0} 313$, de 19 de março de 2020, modifica as regras de suspensão de prazos processuais e dá outras providências. Brasília, DF: DJe/CNJ n. 106/2020, p. 3-4, 2020i. Disponível em:

https://atos.cnj.jus.br/atos/detalhar/3283. Acesso em: 6 jun. 2020.

BRASIL. Resolução n. 318, de 20 de abril de 2020 , do Conselho Nacional de Justiça. Prorroga, no âmbito do Poder Judiciário, em parte, o regime instituído pelas Resoluções $n^{0} 313$, de 19 de março de 2020, e n ${ }^{0} 314$, de 20 de abril de 2020, e dá outras providências. Brasília, DF: DJe/CNJ n. 131/2020, p. 2-3, 2020j. Disponível em: https://atos.cnj.jus.br/atos/detalhar/3308. Acesso em: 6 jun. 2020.

BRASIL. Resolução n. 322, de primeiro de junho de 2020, do Conselho Nacional de Justiça. Estabelece, no âmbito do Poder Judiciário, medidas para retomada dos serviços presenciais, observadas as ações necessárias para prevenção de contágio pelo novo Coronavírus - Covid-19, e dá outras providências. Brasília, DF: DJe/CNJ n. 164/2020, p. 2-4. Republ. DJe n. 166/2020, de 2.6.2020, em decorrência de erro material no art. $5^{\circ}$, VII. 20201. Disponível em: https://atos.cnj.jus.br/atos/detalhar/3333. Acesso em: 6 jun. 2020.

BRASIL. Supremo Tribunal Federal. Ação direta de inconstitucionalidade (ADI) n. 5938/DF. Relator: Ministro Alexandre de Moraes. Julgamento: 29.5.2019. Tribunal Pleno. Publicação: DJe205, 23.9.2019, divulgação em 20.9.2019. Disponível em:

http://www.stf.jus.br/portal/peticaoInicial/verPeticaoInicial.asp?ba $\underline{\mathrm{se}=\mathrm{ADIN} \& \mathrm{~s} 1=5938 \& \text { processo }=5938}$. Acesso em: 25 maio 2020.

BRASIL. Tribunal Superior do Trabalho. Agravo em recurso de revista (ARR) n. 1107-22.2017.5.12.0003. Terceira Turma.

Relator: Alberto Luiz Bresciani De Fontan Pereira.

Julgamento: 27.5.2020. Publicação: 29.5.2020, 2020g. Disponível em: https://jurisprudencia-

backend.tst.jus.br/rest/documentos/32fofa3941e01e128c12225d999 3bo8b. Acesso em: 11 jun. 2020.

BRASIL. Tribunal Superior do Trabalho. Embargos - embargos de declaração - recurso de revista (E-ED-RR) n. 1980017.2004.5.05.0161. Relator: Ministro Renato de Lacerda Paiva.

Subseção de dissídios individuais I. Julgamento: 14.6.2012. Disponível em: https://juslaboris.tst.jus.br/handle/20.500.12178/95689. Acesso em: 12 jun. 2020. 
BRASIL. Tribunal Superior do Trabalho. Livro de súmulas, OJs e PNs. Disponível em: http://www.tst.jus.br/web/guest/livro-desumulas-ojs-e-pns, 2020m. Acesso em: 16 abr. 2020.

BRASIL. Tribunal Superior do Trabalho. Recurso de revista (RR) n. 68906o-75.2000.5.02.5555. Relator: Maria de Assis Calsing. $1^{\text {a }}$ Turma. Publicação: DJ 14.5.2004. Julgamento: 14.4.2004. Disponível em:

https://tst.jusbrasil.com.br/jurisprudencia/955466/recurso-derevista-rr-6890607520005025555-689060-7520005025555. Acesso em: 12 jun. 2020.

CANOTILHO, J.J. Gomes. Direito constitucional e teoria da constituição. 7. ed. Coimbra: Almedina, 2003.

CASSAR, Vólia Bomfim. Direito do trabalho. 15. ed. rev. atual. 2. reimp. Rio de Janeiro: Forense/São Paulo: Método, 2018.

COURA, Alexandre de Castro; FONSECA, Bruno Gomes Borges da. Ministério público brasileiro. Entre unidade e independência. São Paulo: LTr, 2015.

CUEVA, Mario de la. Derecho Mexicano del trabajo. 11. ed. México: Editorial Porrua, 1969.

DELGADO, Mauricio Godinho. Curso de direito do trabalho. 18. ed. São Paulo: LTr, 2019.

DONATO, Messias Pereira. Curso de direito individual do trabalho. 6. ed. São Paulo: Editora LTr, 2008.

FONSECA, Bruno Gomes Borges da; LEITE, Carlos Henrique Bezerra. Limites da aplicabilidade do artigo 15 do novo Código de Processo Civil no processo do trabalho. In: Revista Magister de Direito do Trabalho. São Paulo, v. 79, jul./ago. 2017, p. 54-72.

FREITAS, Ney José de. A suspensão da prescrição em tempo de coronavírus. In: $\mathrm{O}$ direito do trabalho na crise da COVID-19. BELMONTE, Alexandre Agra; MARTINEZ, Luciano; MARANHÃO, Ney. Salvador: Editora JusPodivm, 2020. p. 303-313.

GADAMER, Hans-Georg. Verdade e método II: complementos e índice. 2. ed. Tradução Enio Paulo Giachini. Petrópolis: Vozes/ São Francisco, 2004.

GARCIA, Gustavo Filipe Barbosa. Manual de direito do trabalho. 12. ed. rev. atual. Salvador: Editora JusPodivm, 2019.

GOMES, Orlando. Introdução ao direito civil. 9. ed. Rio de Janeiro: Forense, 1987. 
HERRERO, F. Javier. Ética do discurso. In: OLIVEIRA, Manfredo A. de (org.). Correntes fundamentais da ética contemporânea. 4. ed. Petrópolis: Vozes, 2009.

LEAL, Antônio Luís da Câmara. Da prescrição e da decadência. Teoria geral do direito. 4. ed. Atualizada por José de Aguiar Dias. Rio de Janeiro: Forense, 1982.

LEITE, Carlos Henrique Bezerra. Curso de direito do trabalho. 11. ed. São Paulo: Saraiva, 2019.

LEONARDO, Rodrigo Xavier. A prescrição no código civil brasileiro (ou o jogo dos setes erros). Revista da Faculdade de direito UFPR, Curitiba, n. 51, p. 101-120, 2010. Disponível em: https://revistas.ufpr.br/direito/article/view/30279/19528. Acesso em: 19 ago. 2020.

LÔBO, Paulo. Direito civil. Parte geral. 9. ed. São Paulo: Saraiva Educação, 2020. v. 1. E-book.

MACCORMICK, Neil. Retórica e o Estado de direito: uma teoria da argumentação jurídica. Rio de Janeiro: Elsevier, 2008.

MAIOR, Jorge Luiz Souto. Curso de direito do trabalho. teoria geral do trabalho. São Paulo: LTr, 2011. v. 1.

MARCONI, Marina de Andrade; LAKATOS, Eva Maria.

Metodologia científica. 5. ed. rev. ampl. São Paulo: Editora Atlas, 2007.

MARCONI, Marina de Andrade; LAKATOS, Eva Maria. Técnica de pesquisa. 7. ed. rev. ampl. São Paulo: Editora Atlas, 2010.

MARTINS, Gilberto de Andrade; THEÓPHILO, Carlos Renato. Metodologia da investigação científica para ciências sociais aplicadas. 2. ed. São Paulo: Atlas, 2009.

MIRANDA, Francisco Cavalcanti Pontes de. Tratado de direito privado. Parte geral. Atualizado por Marcos Bernardes de Mello e Marcos Ehrhardt Jr. São Paulo: Revista dos Tribunais, 2013. Tomo V.

MOLINA, André Araújo. Direito do trabalho na pandemia. In:

Revista Eletrônica do Tribunal Regional do Trabalho da $23^{a}$ Região, Mato Grosso, jun. 2020. Disponível em:

https://www4.trt23.jus.br/revista/content/direito-do-trabalho-napandemia?fbclid=IwARoElVDdKa6q6zoGGKyvUtAbgaUtjEuHJN2N JbqYcDtdi8KCigZXuIYU3q4. Acesso em: 12 jun. 2020.

MONTEIRO, Washington de Barros. Curso de direito civil. 45. ed. Atualizada por Ana Cristina de Barros Monteiro França Pinto. São Paulo: Saraiva, 2016. v. I. E-book. 
MONTENEGRO, A. F.; FERRAZ, M. O. Knopik; VILLATORE, M. A. C. Os direitos sociais e os obstáculos à efetivação do princípio da proteção ao hipossuficiente no acesso à jurisdição trabalhista após a publicação da lei n.13.467/2017. Revista Prim@ Facie, João Pessoa, v. 18, n. 37, p. 1-29, 23 maio 2019. Disponível em: https://periodicos.ufpb.br/index.php/primafacie/issue/view/2286/ Prim\%40\%20Facie\%2C\%20n.\%2037\%2C\%2Ov.\%2018\%2C\%202019. Acesso em: 27 jul. 2020.

MORAES FILHO, Evaristo de; MORAES, Antonio Carlos Flores. Introdução ao direito do trabalho. 11. ed. São Paulo: LTr, 2014.

MORAES, José Luiz Bolzan de; MOREIRA, Nelson Camatta. Constitucionalismo, estado de direito e indivisibilidade social que "teima" em continuar. Revista de direitos e garantias fundamentais, Vitória, v. 20, n. 3, p. 11-30, set.-dez. 2019. Disponível em: file:///C:/Users/bgbfo/Downloads/1798-5219-1PB\%20(1).pdf. Acesso em: 19 ago. 2020.

MÜLLER, Friedrich. Métodos de trabalho do direito constitucional. 2. ed. Tradução Peter Naumann. São Paulo: Max Limonad, 2004.

NASCIMENTO, Amauri Mascaro. Curso de direito processual do trabalho. 24 ed. São Paulo: Editora Saraiva, 2009.

NUNES, Dierle José Coelho. Processo jurisdicional democrático. Uma análise crítica das reformas processuais. 4. reimp. Curitiba: Juruá, 2012.

OLIVEIRA, Suélen Ramos de; FONSECA, Bruno Gomes Borges da. Acordo individual, diferenciação a partir do salário e covid19: modificações estruturais na dogmática jurídica do direito do trabalho. 2020. (no prelo).

PAMPLONA FILHO, Rodolfo; FERNANDEZ, Leandro. Prescrição trabalhista e a teoria contra von valentem agere non currit praescriptio. Revista Jurídica Luso-Brasileira, ano 4, n. 1, p. 1255-1278, 2018. Disponível em:

http://www.cidp.pt/revistas/rjlb/2018/1/2018 01 1255 1278.pdf. Acesso em: 19 ago. 2020.

PAMPLONA FILHO, Rodolfo; GAGLIANO, Pablo Stolze. Novo curso de direito civil. 18. ed. São Paulo: Saraiva, 2016. v. 1. Ebook.

PORTUGAL. Código Civil Português. Atualizado de acordo com a Lei n. 85/2019, de 03/09. Disponível em:

https://www.codigocivil.pt/. Acesso em: 19 ago. 2020. 
PORTUGAL. Lei n. 4-A, de 6 de abril de 2020. Procede à primeira alteração à Lei n. 1-A/2020, de 19 de março, que aprova medidas excecionais e temporárias de resposta à situação epidemiológica provocada pelo coronavírus SARS-CoV-2 e da doença COVID-19, e à segunda alteração ao Decreto-Lei n. ${ }^{\circ}$ 10-A/2020, de 13 de março, que estabelece medidas excecionais e temporárias relativas à situação epidemiológica do novo Coronavírus - COVID 19 Disponível em: https://dre.pt/web/guest/pesquisa//search/131193439/details/maximized. Acesso em: 15 jun. 2020.

SANTOS, Leonardo Valverde Susart dos Santos. A incompatibilidade do regime de contagem do prazo prescricional no curso do vínculo empregatício com o princípio da proteção ao trabalho. Revista dos Tribunais, São Paulo, v. 972/2016, p. 249-271, out. 2016.

SEVERO, Valdete Souto. Crítica à prescrição trabalhista: entre a realização do estado social e a proteção ao capital. In: Revista Acadêmica da Faculdade de Direito de Recife. v. 89, n. 1, p. 99-124, jan.-jun. 2017. Disponível em:

https://periodicos.ufpe.br/revistas/ACADEMICA/article/view/2296 3. Acesso em: 5 jun. 2020.

SILVA, De Plácido e. Vocabulário jurídico. 28. ed. atualizada por Nagib Slaibi Filho e Gláucia Carvalho. Rio de Janeiro: Editora Forense, 2009.

SÜSSEKIND, Arnaldo; MARANHÃO, Délio; VIANNA, Segadas; TEIXEIRA, Lima. Instituições de direito do trabalho. 18 ed. atualizada por Arnaldo Süssekind e João de Lima Teixeira Filho. São Paulo: LTr, 1999. v. I.

THEODORO JÚNIOR, Humberto. Prescrição e decadência. Rio de Janeiro: Forense, 2018.

VALENTE, Nara Luiza; FOGAÇA, Vitor Hugo Bueno; SILVA, Silmara Carneiro e. A reforma trabalhista brasileira e retrocessos na garantia de direitos fundamentais do trabalhador. Revista Prim@ Facie, João Pessoa, v. 17, n. 35, p. 1-32, 25 set. 2018. Disponível em: https://periodicos.ufpb.br/index.php/primafacie/article/view/38814 L20918. Acesso em: 19 ago. 2020.

VIANA, Márcio Túlio. Os paradoxos da prescrição: quando o trabalhador se faz cúmplice involuntário da perda de seus direitos. In: Revista do Tribunal Regional do Trabalho da $3^{\mathbf{a}}$ Região, Belo Horizonte, v. 47, n. 77, p. 163-172, jan./jun. 2008.

WALD, Arnoldo; CAVALCANTI, Ana Elizabeth L. W; PAESANI, Liliana Minardi. Direito civil: introdução e parte geral. 14. ed. São Paulo: Saraiva, 2015. v. 1. E-book. 
A Suspensão Da Prescrição Trabalhista Em Tempos De Pandemia

WARAT, Luiz Alberto. Introdução geral ao direito. Interpretação da lei. Temas para uma reformulação. Porto Alegre: Sergio Antonio Fabris Editor, 1994. v. I.

WITTGENSTEIN, Ludwig. Investigações filosóficas. 6. ed. Tradução Marcos G. Montagnoli. Petrópolis: Vozes, 2009. 


\title{
The Suspension Of The Labor Limitation Period In Times Of Pandemic
}

\author{
Bruno Gomes Borges da Fonseca
}

Vitor Salino de Moura Eça

Stela Barbas

\begin{abstract}
This article analyzed if a pandemic, such as the one generated by the Sars$\mathrm{CoV}-2$ virus (coronavirus), has the capacity to prevent or suspend the limitation period of the claim for labor rights. The hypothesis was that the limitation period on labor rights, in this situation of abnormality, do not begin to count or are suspended, based on an interpretation based on the right of access to jurisdiction. The research was justified due to numerous legal controversies that arose from the pandemic, including about the counting of the limitation period. The objectives of this research were: to analyze the limitation period in its general aspects, as well as to analyze the impediment and the suspension of the counting of the labor limitation period during the pandemic, based on the example of covid-19. The dialectic approach proved adequate due to the possibility of extracting contradictions and antagonisms around the limitation period of labor claims and for signaling alternatives at a pandemic moment. As a result, it was concluded that the cases of impediment and suspension of the limitation period, set out in the Brazilian Civil Code, are applicable to labor law. However, they should be analyzed from a constitutional point and with the observation that the limitation period, in this specialized legal branch, has restrictions and particularities. In addition, pandemics, such as that generated by the Sars-CoV-2 virus (coronavirus), may result in the interruption or suspension of the counting of the limitation period of claims arising from violations of labor rights, if there is evidence of obstacle or justifiable impediment for the access to jurisdiction, something confirmed, in part, by the Brazilian Law n. 14.010/2020.
\end{abstract}

Keywords: Labor law. Labor Procedure. Covid-19. Coronavirus. Limitation period.

DOI: https://doi.org/10.22478/ufpb.1678-2593.2020v19n42.53334

Conteúdo sob licença Creative Commons: Attribuition-NonCommercial-NoDerivative 4.o International (CC BY-NC-ND 4.0) 